\title{
ZAGLADA W MYŚLI JANA PAWŁA II I TWÓRCZOŚCI ARNOLDA SCHÖNBERGA ${ }^{1}$
}

Zestrojenie dwóch, pozornie pozostających z sobą bez związku, postaci: Jana Pawła II i Arnolda Schönberga, może się wydawać zaskakujące. Jednak to nie relacja między osobami jest tu istotna, lecz pewna cechująca je wspólnota postaw wobec zagadnień relacji międzyludzkich, praw człowieka, godności i poczucia zjednoczenia w obliczu niezwykle trudnych doświadczeń historycznych. Jest to mianowicie postawa wyrażająca uznanie wyższości jedności ponad wszelkim dystansem i podziałem; postawa głęboko humanistyczna i głęboko duchowa, jako wspólnota myśli bez względu na wyznawaną religię.

Pojednanie chrześcijaństwa i judaizmu poprzez dialog, którego Jan Paweł II pozostaje inicjatorem, a w rezultacie wręcz symbolem, miało miejsce na gruncie właśnie takiego rozumienia wspólnoty ludzi, bez względu na ich wiarę, jako ofiar jednej z najbardziej wstydliwych kart historii - Zagłady. Uderzające jest w tym zakresie pokrewieństwo postawy Jana Pawła II i Arnolda Schönberga, przejawiające się zwłaszcza w trzech aspektach charakterystycznych dla ich myśli. Są to: prawa człowieka, potrzeba świadectwa Zagłady oraz odpowiedzialność historyczna, szczególnie w świetle doświadczeń II wojny światowej. Jan Paweł II mówił w Auschwitz:

Jeśli jednakże to wielkie wołanie Oświęcimia, krzyk umęczonego tu człowieka ma przynieść owoce dla Europy (a także dla świata), trzeba wyciągnąć wszystkie słuszne konsekwencje z Deklaracji Praw Człowieka, jak do tego wzywał Jan XXIII w encyklice Pacem in terris. Czytamy tam między innymi: „Deklaracja ta uroczyście przyznaje wszystkim bez wyjątku ludziom godność osoby ludzkiej, potwierdza prawo każdego człowieka do swobodnego poszukiwania prawdy, do zachowania norm moralności,

1 Publikacja powstała w wyniku realizacji projektu badawczego o nr 2016/21/N/HS2/02676 finansowanego ze środków Narodowego Centrum Nauki. 
do pełnienia sprawiedliwości, do wymagania warunków życia godnych człowieka: są to prawa powszechne, nienaruszalne i niezbywalne"2.

Refleksja Schönberga dotycząca praw ludzkich pojawiła się również jako wyraz sprzeciwu wobec okrucieństwa wojennego. W jego pismach z 1947 roku, a więc zaledwie rok przed uchwaleniem przez ONZ Powszechnej Deklaracji Praw Człowieka, znajdujemy sformułowania stanowiące wyraz podobnej postawy:

Należy dążyć do sformułowania pewnego minimum praw niezmiennie obowiązujących dla wszystkich ludzi wszystkich ras. [...] To są prawdziwe problemy i łatwo stać się pesymistą, gdy się o nich myśli. Niemniej nigdy nie wolno zrezygnować z dążenia do uniwersalnego uświęcenia praw ludzkich. W naszej duszy istnieje taka właśnie możliwość dążenia, cechująca się mocą sprawczą ${ }^{3}$.

Co do ważkości świadectwa Zagłady Jan Paweł II mówił w Yad Vashem: „Świat musi usłyszeć przestrogę, jaką pozostawiły nam ofiary Holokaustu i jakim są świadectwa ocalonych" ${ }^{4}$. U Schönberga motyw ten stanowi główne przesłanie Ocalałego z Warszawy op. 46. Świadectwo Ocalałego..., łącząc się nierozdzielnie ze świadectwem, w pewnym sensie pośrednim, samego kompozytora, stanowi zarówno przestrogę, jak i przesłanie nadziei poprzez jedność w wierze. W poruszających słowach wygłoszonych podczas mszy świętej odprawionej na terenie byłego obozu koncentracyjnego Jan Paweł II mówił:

Oświęcim jest świadectwem wojny. To wojna niesie z sobą ów nieproporcjonalny przyrost nienawiści, zniszczenia, okrucieństwa. A jeśli nie da się zaprzeczyć, że objawia również inne możliwości ludzkiej odwagi, bohaterstwa, patriotyzmu, to jednak rachunek strat przeważa. Coraz bardziej przeważa - im bardziej wojna staje się rozgrywką wyrachowanej techniki zniszczenia. Za wojnę są odpowiedzialni nie tylko ci, którzy ją bezpośrednio wywołują, ale również ci, którzy nie czynią wszystkiego, co leży w ich mocy, aby jej przeszkodzićs.

2 Jan Paweł II, Homilia w czasie mszy św. odprawionej na terenie byłego obozu koncentracyjnego, https://ekai.pl/dokumenty/homilia-w-czasie-mszy-sw-odprawionej-naterenie-bylego-obozu-koncentracyjnego (14.10.2017).

3 A. Schoenberg, Human Rights, [w:] Style and Idea, Berkeley 2010, s. 507, 512; tłum. Iwona Sowińska-Fruhtrunk (o ile nie podano inaczej, wszystkie tłumaczenia pochodzą od autorki).

4 Wizyta w Yad Vashem, http://www.nauczaniejp2.pl/dokumenty/wyswietl/id/1042/pos/ 7/haslo (14.10.2017).

${ }^{5}$ Jan Paweł II, Homilia w czasie mszy św. odprawionej na terenie byłego obozu koncentracyjnego, dz. cyt. 
Dla Schönberga jest to kwestia wielkiej wagi, gdyż poczucie takiej właśnie odpowiedzialności było jego udziałem; co więcej, podejmował on w tym zakresie działania niemające odpowiedników wśród ówczesnych przedstawicieli środowiska artystycznego.

\section{Schönberg: religia i polityka}

Choć droga wiodąca Schönberga do judaizmu była nieoczywista i skomplikowana, jego zainteresowanie szeroko pojętą problematyką religii trwało całe życie. Nastroje antysemickie narastające w Europie lat 20. XX wieku uwrażliwiły kompozytora na kwestie światopoglądowe. Rok 1923 był naznaczony kryzysem jego przyjaźni z Wasylem Kandynskym (trwającej od 1911 roku) z powodu antysemickich komentarzy czynionych rzekomo przez malarza. W liście do Kandynsky'ego z 20 kwietnia 1923 roku Schönberg pisał:

Wreszcie zrozumiałem naukę, którą wtłaczano mi siłą w ciągu tego roku, i nigdy jej nie zapomnę. Oznacza to, że nie jestem Niemcem, ani Europejczykiem, w rzeczywistości zaledwie nawet istotą ludzką [...], lecz jestem Żydem. [...] Dotarło do mnie, że nawet Kandinsky widzi jedynie zło czynione przez Żydów, a w ich złych uczynkach jedynie żydostwo. I to mnie zmusza do porzucenia nadziei na osiągnięcie zrozumienia. To był sen. Stanowimy dwa rodzaje ludzi. Nieodwołalnie! 6 .

Kolejny list przynosi jeszcze bardziej dramatyczne przewidywania kompozytora:

Lecz do czegóż doprowadzi antysemityzm, jeśli nie do aktów przemocy? Czy tak trudno to sobie wyobrazić? Jesteś być może usatysfakcjonowany odebraniem Żydom ich cywilnych praw. W takim razie z pewnością Einstein, Mahler, ja i wielu innych zostanie unicestwionych? ${ }^{7}$.

W 1925 roku kompozytor przeprowadził się z Wiednia do Berlina, gdzie wraz z nadejściem lat 30. sytuacja polityczna stawała się coraz bardziej napięta. W 1932 roku napisał w liście do Albana Berga: „Wbijano mi to do głowy tak głośno i tak długo, iż musiałbym być głuchy, żeby nie zrozumieć. I już od dłuższego czasu nie jestem z tego powodu rozżalony. Dzisiaj z dumą nazywam siebie Żydem”». Jesz-

${ }^{6}$ M. DeVoto, Arnold Schoenberg and Judaism: The Harder Road, wykład wygłoszony w Hebrew Union College - Jewish Institute of Religion, New York 1993, s. 4, http://emerald. tufts.edu/ mdevoto/Schoenberg.pdf (23.05.2015).

7 M. DeVoto, Arnold Schoenberg and Judaism, dz. cyt., s. 5.

8 A. Schoenberg, Letters, tłum. na j. angielski E. Wilkins, E. Kaiser, New York 1965, s. 167. 
cze przed emigracją do Stanów Zjednoczonych, kompozytor obmyślał odważny projekt i naszkicował plan z intencją

[...] zaangażowania propagandy na dużą skalę wśród Żydów w Stanach Zjednoczonych, a później w innych krajach, przede wszystkim z myślą o zdobyciu środków finansowych wystarczających na opłacenie stopniowej emigracji Żydów z Niemiec?.

W przytoczonych słowach zwraca uwagę niezwykła przenikliwość spojrzenia dotycząca spraw politycznych, a także słuszne obawy kompozytora o przyszłość narodu żydowskiego.

24 lipca 1933 roku, tuż przed wyjazdem do Ameryki, Schönberg wstąpił ponownie do gminy żydowskiej w Paryżu, składając formalną deklarację wiary ${ }^{10}$. Świadkami byli Dimitri Marianoff i Marc Chagall. Akt ten miał dla kompozytora znaczenie symboliczne, jako forma solidaryzowania się z ofiarami rosnących nastrojów antysemickich w Europie. Podczas pobytu w Stanach Zjednoczonych Schönberg próbował obudzić w różnych środowiskach świadomość dramatycznej sytuacji europejskich Żydów, jednak bez większych sukcesów z uwagi na „generalną obojętność Ameryki w stosunku do ponurych wydarzeń w Niemczech"11. Nasuwa się tu porównanie z reakcjami Zachodu na raport Jana Karskiego. Kompozytor pisał: „Zdecydowałem się poświęcić wszystkie poprzednie formy aktywności, jako kompozytor, pisarz, teoretyk i tak dalej, aby od teraz zająć się tylko jedną sprawą: pracą zmierzającą do uratowania Żydów"12. W 1934 roku Schönberg napisał nawet do Rabina Stephena Wise’a, stojącego na czele Amerykańskiego Kongresu Żydów:

Nie mam żadnych ambicji politycznych: moje ambicje byłyby zupełnie zaspokojone na papierze w pięciolinie, gdybym w ogóle jakieś miał. Dążę jedynie do niesławnego honoru poświęcenia mojego życia dla ocalenia egzystencji Żydów. I tylko wtedy, gdy nie znajdzie się bardziej odpowiednia osoba, przede wszystkim młodsza i zdrowsza ode mnie, tylko wtedy, aby nie wymigać się od oczywistego obowiązku, będę skłonny uczynić krok naprzód ${ }^{13}$.

Jednak z braku wiedzy nie pojmowano wówczas grozy sytuacji i nie podjęto żadnych działań. Dla Kongresu, który reprezentował przede wszystkim amerykańskich „zasymilowanych Żydów”, takie działania wobec nazistów w latach 30. były

9 M. Strasser, „A Survivor from Warsaw” as Personal Parable, „Music \& Letters” 76 (1995) nr 1, s. 57; zob. także: A. L. Ringer, Arnold Schoenberg: the Composer as Jew, Oxford 1990, s. 135.

${ }_{10}$ Por. M. DeVoto, Arnold Schoenberg and Judaism..., dz. cyt., s. 7.

${ }_{11}$ M. DeVoto, Arnold Schoenberg and Judaism..., dz. cyt., s. 8.

12 S. Feisst, Schoenberg's New World: The American Years, Oxford 2011, s. 86.

13 M. DeVoto, Arnold Schoenberg and Judaism..., dz. cyt., s. 8. 
nie do pomyślenia ${ }^{14}$. W grudniu 1938 roku Schönberg ukończył Czteropunktowy program dla Żydów, przygotowywany od wielu lat. Przede wszystkim nawoływał do podjęcia przez naród żydowski próby zdobycia za wszelką cenę własnej ziemi, zamiast kontynuowania walki przeciwko antysemityzmowi, kosztującej jedynie utratę cennego czasu i energii ${ }^{15}$. Kompozytor ostrzegał w początkowym paragrafie, że miliony europejskich Żydów znajdują się w niebezpieczeństwie, i pytał: „czy znajdzie się miejsce dla prawie 7000000 ludzi? Czy są oni skazani na zagładę? Wyginą? Zostaną zagłodzeni? Zmasakrowani?” ${ }^{16}$. Konkluzja brzmiała: „czas słów się skończył i jeżeli nie zostaną natychmiast podjęte działania, może być za późno"17. Nie było mu jednak dane, mimo wielu starań, opublikować tekstu Progra$m u$. Jedynym marzeniem Schönberga, którego spełnienia doczekał, było powstanie państwa izraelskiego. Poświęcił tej okazji utwór (nieukończony) do własnego tekstu Israel exists again, skomponowany w 1949 roku.

\section{Ocalaly $z$ Warszawy op. 46 - geneza}

Ocalały z Warszawy powstał w dość krótkim czasie między 11 a 23 sierpnia 1947 roku, jednak praca nad utworem rozpoczęła się już kilka miesięcy wcześniej. Pomysłodawczynią dzieła była Corinne Chochem, tancerka rosyjskiego pochodzenia $^{18}$, która przysłała Schönbergowi muzykę i słowa „pieśni partyzanckiej śpiewanej w wileńskim getcie"19. Około trzech tygodni później kompozytor odpowiedział na list, podając kilka szczegółów planowanego dzieła:

[...] 6-9 minut na małą orkiestrę i chór, być może także jednego lub więcej solistów do melodie, którą mi dałaś. Planuję umieścić tę scenę - którą opisujesz - w warszawskim getcie, gdzie skazani na zagładę Żydzi zaczynają śpiewać tuż przed śmiercią ${ }^{20}$.

Kilka tygodni później Fundacja Muzyczna Kusewickiego zwróciła się do niego z zamówieniem dzieła orkiestrowego. Schönberg odpisał 14 lipca 1947 roku:

Trochę więcej niż miesiąc temu zacząłem pracować nad kompozycją na orkiestrę [...]. Chciałbym oznajmić, że jeszcze nie zdecydowałem o ostatecznym kształcie

14 Por. S. Feisst, Schoenberg's New World..., dz. cyt., s. 87.

15 Por. M. DeVoto, Arnold Schoenberg and Judaism..., dz. cyt., s. 8.

16 S. Feisst, Schoenberg's New World..., dz. cyt., s. 86.

${ }_{17}$ S. Feisst, Schoenberg's New World..., dz. cyt, s. 87.

18 Por. M. Strasser, „A Survivor from Warsaw”..., dz. cyt., s. 52.

19 M. Strasser, „A Survivor from Warsaw”..., dz. cyt., s. 52.

20 M. Strasser, „A Survivor from Warsaw”..., dz. cyt., s. 52. 
tego utworu. Moim oryginalnym planem była kompozycja na małą grupę około 24 muzyków, jednego lub dwóch „recytatorów” i chór męski o odpowiedniej obsadzie. Wciąż jeszcze jestem w stanie uczynić ten utwór „poematem symfonicznym” na standardową orkiestrę bez recytatora i chóru - jeżeli zamówienie tego wymaga ${ }^{21}$.

Po otrzymaniu od Fundacji swobody decyzji kompozytor napisał 24 sierpnia 1947 roku, co następuje:

Jest mi miło poinformować, że zamówiony utwór [...] jest gotowy. Nie mogłem przekształcić kompozycji w poemat symfoniczny, tak jak miałem nadzieję to zrobić. To by nie było to, co chciałem wyrazić. Ale, pomimo że uwzględniłem jednego recytatora i chór męski, mogłem przynajmniej wyeliminować drugiego recytatora - wymagało to wielu zmian!22.

Na skutek niedomówień pomiędzy artystą a Fundacją prawykonanie dzieła odbyło się nie w Bostonie, lecz w niewielkim mieście Albuquerque w Nowym Meksyku (4 listopada 1948 roku) i odniosło ogromny sukces.

\section{Tekst literacki}

Libretto Ocalałego..., autorstwa kompozytora, jest zapisem chaotycznej narracji, opisującej pełne przemocy wydarzenia z getta czy obozu, gdzie powtarzający się nakaz odliczania więźniów i groźba wysłania do komory gazowej doprowadzają do ich symbolicznego buntu - odśpiewania jednej z najważniejszych modlitw żydowskich w języku hebrajskim, Shema Yisroel. W tekście zawarte są wskazówki pozwalające na potencjalne uwzględnienie przynajmniej dwóch (a nawet trzech) różnych miejsc akcji: warszawskiego getta i obozu koncentracyjnego (gdyż dopiero tam dokonywana była selekcja). Można także podejrzewać, że sytuacja odliczania więźniów miesza trzy różne miejsca: regularne odliczanie podczas codziennego porannego apelu, odliczanie do transportu z getta (Umschlagplatz) i odliczanie przed wysłaniem do komory gazowej. Rzeczywistość przywoływana przez Narratora ma charakter quasi-oniryczny. Zgodnie z wieloma świadectwami ocalałych, sceny z obozu często powracają w snach ${ }^{23}$. Doświadczenie czasu ulega wówczas zniekształceniu. Jak pisze Giorgio Agamben:

${ }^{21}$ M. Strasser, „A Survivor from Warsaw”..., dz. cyt., s. 54.

22 M. Strasser, „A Survivor from Warsaw”..., dz. cyt., s. 54.

${ }_{23}$ Por. P. Levi, Se questo è un uomo, Torino 1988, s. 254-255, cyt. za: G. Agamben, Co zostaje z Auschwitz, tłum. S. Królak, Warszawa 2008, s. 103-104. 
Auschwitz oznacza nieodwołalny kryzys właściwej czasowości, samej możliwości „Zdecydowania” o rozdzieleniu. Obóz jako sytuacja absolutna oznacza zniesienie wszelkiej możliwości źródłowej czasowości, czyli czasowego ugruntowania jakiejś określonej sytuacji w przestrzeni, w $D a^{24}$.

Co do tytułu utworu, Michael Strasser uważa, że „powstanie w warszawskim getcie miało szczególne znaczenie dla Schönberga, tak jak i dla wszystkich Żydów gdyż tam stawili opór. [...] Powstanie w warszawskim getcie było największym i najbardziej znanym buntem i stało się uniwersalnym i inspirującym symbolem niezniszczalności ludzkiego ducha" ${ }^{25}$. Nie wiadomo do końca, z ilu i jakich źródeł Schönberg czerpał inspirację. René Leibowitz donosi, że osnową była historia opowiedziana kompozytorowi przez młodego człowieka, ocalałego z warszawskiego getta $^{26}$. Sam kompozytor tak komentował tekst utworu:

[...] oto, co oznacza dla mnie tekst Ocalałego: przede wszystkim oznacza ostrzeżenie dla wszystkich Żydów, aby nigdy nie zapomnieli, co im wyrządzono, i nigdy nie zapomnieli, że nawet ludzie, którzy nie zrobili tego osobiście, wyrazili na to zgodę i uznali za konieczne potraktować nas w ten sposób. Nie powinniśmy nigdy tego zapomnieć, nawet jeżeli odbyło się to w inny sposób, niż opisuję w Ocalałym. To nie ma znaczenia. Najważniejsze jest, że widziałem to w mojej wyobraźni ${ }^{27}$.

Tekst utworu jest poniekąd rodzajem tekstu autobiograficznego, na którego określenie Florian Znaniecki wprowadził pojęcie „dokumentu osobistego”, a które z kolei ewoluowało dzięki Romanowi Zimandowi w stronę terminu „literatura dokumentu osobistego" ${ }^{28}$. Jacek Leociak pisze:

Specyfikę literatury dokumentu osobistego wyznaczają trzy podstawowe właściwości: po pierwsze - płynność granic międzygatunkowych i łatwość ich przekraczania, mająca swe źródło w spersonalizowanej narracji; po drugie - rozmycie opozycji między „prawdą” a „zmyśleniem”, którego źródłem jest gra między referencyjnością

24 G. Agamben, Co zostaje z Auschwitz, dz. cyt., s. 131.

25 G. Agamben, Co zostaje z Auschwitz, dz. cyt., s. 61.

26 Por. R. Leibowitz, Introduction á la musique de douze sons, Paris 1949, s. 322-323.

27 Z listu Arnolda Schönberga do Kurta Lista (1 listopada 1948), cyt. za: A. L. Wlodarski, "An Idea Can Never Perish": Memory, the Musical Idea, and Schoenberg's A Survivor from Warsaw (1947), „The Journal of Musicology” 24 (2007) nr 4, s. 586.

${ }^{28}$ J. Leociak, Literatura dokumentu osobistego jako źródło do badań nad zagładą Żydów. Rekonesans metodologiczny, [cyt. za:] K. Koprowska, Podmiotowość wobec doświadczenia granicznego w świadectwach ocalałych muzułmanów, „Wielogłos. Pismo Wydziału Polonistyki UJ” (2013) nr 3(17), s. 6-7. 
tekstu a kompozycyjnymi regułami opowiadania; po trzecie - wielka różnorodność gatunków i odmian ${ }^{29}$.

Leociak wprowadza ponadto podział na teksty pisane hic et nunc oraz post factum, jak w przypadku Ocalałego.... ${ }^{30}$

W utworze łączą się dwa rodzaje doświadczenia: realnego świadka i kompozytora współdoświadczającego przeszłość dzięki swojej wrażliwości, współczuciu i wyobraźni muzycznej. Doświadczenie Zagłady przenika doświadczenie zmierzenia się z nią poprzez muzykę. Trzeba zaznaczyć, że Narrator jest tutaj podwójnym świadkiem: najpierw przywołującym wspomnienie przeszłości, a następnie przeżywającym je na nowo. Amy Lynn Wlodarski posługuje się terminem „świadka drugiego stopnia” na określenie pozycji kompozytora ${ }^{31}$. Należy pamiętać, że Schönberg nie tylko nie uwzględnił pełnego, oryginalnego świadectwa ocalałego z Zagłady, lecz, zainspirowany takimi świadectwami, opracował tekst w artystyczny sposób, zgodnie ze swoimi estetycznymi i ideowymi przekonaniami. W związku z tym Ocalały... już na poziomie warstwy literackiej nie może być uznany za reprezentację historyczną. Jak zauważa Wlodarski, „świadek muzyczny uosabia [...] relację dialogiczną między sztuką, historią i pamięcią"32.

Obecność w dziele trzech języków: angielskiego, niemieckiego (pruskiego) i hebrajskiego, stanowi wyjątek w twórczości Schönberga (poza Ocalałym... jedynie tekst Psalmu 130 „De Profundis” op. 50B jest napisany w języku hebrajskim). Angielski jako język Ocalałego... ma w utworze status neutralny. Niemiecki zostaje wprowadzony do narracji za pomocą przywołania w pamięci Narratora postaci sierżanta, którego kwestie wyrażone w czasie teraźniejszym (w mowie niezależnej) przyczyniają się, według Davida Liebermana, do powstania wrażenia pewnej „izolacji lingwistycznej" ${ }^{33}$. Tekst w języku angielskim i niemieckim umuzyczniony został wyłącznie poprzez Sprechstimme, technikę szczególnie znacząco wykorzystywaną przez Schönberga w utworach o wydźwięku religijnym i politycznym (Drabina Jakubowa, Mojżesz i Aron, Psalm 130, Moderner Psalm, Oda do Napoleona). Jak pisze Mark Risinger, Sprechstimme staje się tutaj środkiem ekspresji utożsamionym z ideą Boga ${ }^{34}$. Warto jednak zauważyć, że punkt ciężkości spoczywa bardziej na poszukiwaniu

29 J. Leociak, Literatura dokumentu osobistego..., dz. cyt., s. 7.

${ }^{30}$ J. Leociak, Literatura dokumentu osobistego..., dz. cyt., s. $7 .$.

31 Por. A. L. Wlodarski, Musical Witness and Holocaust Representation, Cambridge 2015, s. 18.

32 A. L. Wlodarski, Musical Witness..., dz. cyt., s. 2.

${ }_{33}$ D. I. Lieberman, Schoenberg Rewrites His Will. A Survivor from Warsaw, Op. 46, [w:] Political and Religious Ideas in the Works of Arnold Schoenberg, eds. Ch. A. Cross, R. A. Berman, New York-London 2000, s. 215.

${ }^{34}$ Por. M.P. Risinger, Schoenberg's Modern Psalm, Op. 50c and the Unattainable Ending, [w:] Political and Religious Ideas..., dz. cyt., s. 300. 
niż potwierdzaniu, o czym może świadczyć fakt, że fragmenty modlitewne są z kolei śpiewane (jak np. Shema Yisroel w Ocalałym $z$ Warszawy) w języku hebrajskim.

Kompozytor wykorzystuje w utworze grupę charakterystycznych i powtarzających się motywów dźwiękowo-rytmicznych, podkreślających uporczywość powracania przeżytych wydarzeń w pamięci Narratora. Większość z nich jest skojarzona z obecnymi w tekście odniesieniami do przemocy, upokorzenia, cierpienia, strachu. Mimo że utwór opiera się na materiale dodekafonicznym (choć traktowanym swobodnie), to pierwsze pojawienie się pełnej serii w postaci zasadniczej związane jest z ukazaniem modlitwy Shema Yisroel, co może świadczyć o podkreśleniu jedności w wierze i solidarności kompozytora z ofiarami Zagłady. Znaczącą funkcję ilustracyjną pełni w Ocalałym $z$ Warszawy instrumentacja, zwłaszcza instrumenty perkusyjne towarzyszące wypowiedziom sierżanta i podkreślające opisy aktów fizycznej przemocy. Jednym z ważniejszych i jednocześnie otwierającym dzieło motywem jest fanfara trąbki, jako ilustracja bezwzględnej obozowej pobudki. Militarny charakter tej fanfary budzi skojarzenia nie tylko z symfoniami Gustawa Mahlera, ale także z „niemieckim heroizmem” dramatów muzycznych Ryszarda Wagnera, wykorzystywanych w III Rzeszy do celów propagandowych ${ }^{35}$. Szczególną uwagę zwraca powierzenie antycypacji melodii modlitwy w introdukcji puzonowi (który także dubluje Shema Yisroel na końcu utworu), instrumentowi kojarzonemu nie tylko w historii muzyki, ale i w całej niemieckiej tradycji kulturowej z wezwaniem na Sąd Ostateczny. Istotną rolę ilustracyjną odgrywa także artykulacja, obejmująca całą gamę środków: col legno, col legno battuto, col legno tratto, ponticello, con sordino, saltando, pizzicato, frullato. Percepcja tego zróżnicowania jest ułatwiona dzięki skameralizowaniu obsady orkiestrowej. Podobnie jak pozostałe elementy muzyczne, artykulacja służy ilustracji tekstu słownego, np. szybkim, chaotycznym krokom więźniów towarzyszą uderzenia smyczkiem col legno, natomiast wszelkim momentom strachu i niepewności - artykulacja sul ponticello.

\section{Wymiary przestrzenne według Mieczysława Tomaszewskiego}

Mieczysław Tomaszewski wyznacza trzy podstawowe wymiary przestrzenne, w których „bytuje” człowiek ${ }^{36}$ : podłużny, poprzeczny i pionowy, jako „punkt wyjścia dla zarysowania struktury elementarnych odpowiedniości” ${ }^{37}$ ponownego zejścia się słowa i muzyki. Wymiar podłużny oznacza ciągłość, kontynuację: imitującą lub

35 Por. D. I. Lieberman, Schoenberg Rewrites His Will..., dz. cyt., s. 216-217.

36 Por. K. Kiwała, Dzieło symfoniczne w perspektywie polskich koncepcji fenomenologicznych. Lutosławski, Górecki, Penderecki, Kraków 2013, s. 389.

37 M. Tomaszewski, Muzyka w dialogu ze słowem, Kraków 2003, s. 145-151. 
przekształcającą; odpowiada mu metafora drogi ${ }^{38}$. W literaturze odpowiada bardziej biegowi prozy, narracji. W myśleniu metaforycznym kojarzy się z historią ludzkości i biografią człowieka, w przeciwieństwie do geografii kultury czy układu społecznego $^{39}$. Wymiar poprzeczny oznacza zawieszenie czasu i wyraża się poprzez metaforę domu ${ }^{40}$. I wreszcie wymiar pionowy, „otwarty w górę i w dół”, odpowiada temu, co chwilowe, momentowe i nagłe. Jest metaforą stopni, schodów, drabiny ${ }^{41}$. W muzyce kojarzy się on $\mathrm{z}$ „działaniem dynamiki i akcentuacji, wyraża się motywem lub akordem bardziej niż tematem; nagłą pauzą generalną”"2. Jak pisze autor: „w ostatecznej instancji przynosi rozróżnienie na tematykę sacrum i profanum; obraca się między sferą Biblii i mitologii a sferą życia prywatnego i najgłębszego tabu" ${ }^{\prime 3}$. W Ocalalym $z$ Warszawy te dwie sfery zostają sobie przeciwstawione właśnie za pomocą skonfrontowania dwóch wymiarów: fragmentarycznej, lapidarnej struktury rytmiczno-motywicznej oraz narracji utrzymanej w Sprechstimme i recytacji symbolizujących wymiar pionowy i tematykę profanum oraz linearności, ciągłości i kontynuacji (rozumianej również metaforycznie) śpiewanej modlitwy symbolizującej wymiar podłużny i tematykę sacrum. Na obecność wymiarów pionowego i podłużnego wskazują także dwie przeciwstawne wyrazowo kulminacje: ekspresywna i dynamiczna. Pierwsza z nich jest rodzajem antykulminacji - stanowi ją akord subito ppp przedłużony fermatą, na tle którego padają słowa groźby wysłania do komory gazowej. W warstwie muzycznej powstaje efekt całkowitego zatrzymania, „zamrożenia” ruchu, natomiast w warstwie semantycznej - wycofania, „zapadnięcia się" w sobie wobec ogromu przemocy i poniżenia. Ów bezruch przedstawia sugestywnie groźbę wiecznej nieobecności, unicestwienia, zagłady. Drugą kulminację, dynamiczną, stanowi wybuch Shema Yisroel z poprzedzającego, narastającego rytmicznie i brzmieniowo odliczania więźniów (ostinato). Momentowość i tendencja do odchodzenia w niepamięć historii ulegają zderzeniu z wiecznością i nieśmiertelnością wiary.

\section{„Doświadczenie, którego nie ma”44}

Doświadczanie świata przez kompozytora, ujawnione następnie w muzyce, odsyła nas nie tylko do genezy dzieła i szczegółów biograficznych. Jest rodzajem

38 Por. K. Kiwała, Dzieło symfoniczne..., dz. cyt., s. 389.

39 Por. M. Tomaszewski, Muzyka w dialogu ze stowem, dz. cyt., s. 148.

40 Por. K. Kiwała, Dzieło symfoniczne..., dz. cyt., s. 390.

${ }^{41}$ K. Kiwała, Dzieło symfoniczne..., dz. cyt., s. 391.

${ }^{42}$ K. Kiwała, Dzieło symfoniczne..., dz. cyt., s. 391.

${ }^{43}$ M. Tomaszewski, Muzyka w dialogu ze słowem, dz. cyt., s. 151.

${ }_{44}$ R. Nycz, Poetyka doświadczenia. Teoria - nowoczesność - literatura, Warszawa 2012, s. 142 . 
oświadczenia, świadectwa „przetworzonego” przez sztukę. Jednym z najdramatyczniejszych „doświadczeń” XX wieku, uzewnętrznionym w sztuce na rozmaite sposoby, było doświadczenie Zagłady - jak pisze Ryszard Nycz - „doświadczenie, którego nie ma”, gdyż „ma prawo nasunąć się wątpliwość, czy mamy tu jeszcze w ogóle do czynienia z doświadczeniem?" ${ }^{45}$. Mimo to doświadczenie Zagłady silnie uzewnętrzniło się nie tylko w twórczości kompozytorów, którzy byli świadkami II wojny światowej, ale także późniejszych, którym nie było ono dane „bezpośrednio” i dla których stanowiło właśnie rodzaj rozrachunku z przeszłością. Estetyczne doświadczenie muzyki ustąpiło tu miejsca doświadczeniu etycznemu.

Gdy Paul Ricœur zadaje pytanie: „czyż stosunek do przeszłości nie może być odmianą mimēsis?"46, prawdopodobnie ma na myśli trudność uchwycenia prawdziwej tożsamości przeszłych wydarzeń oraz dokonania rozróżnienia pomiędzy pamięcią i wyobraźnią. Ernst van Alphen uważa, że „problem nie leży w naturze wydarzenia ani w nieodłącznych ograniczeniach reprezentacji; stanowi raczej rozłam między przeżywaniem wydarzenia i dostępnymi formami reprezentacji, poprzez które może być doświadczony" ${ }^{47}$. Fakt, że Schönberg rozważał początkowo gatunek poematu symfonicznego i ostatecznie nie zdecydował się na tę formę wyrazu, oddaje jego wątpliwości natury zarówno formalnej i ekspresywnej, jak i przedstawieniowej. Zagłada jest często nazywana doświadczeniem niereprezentowalnym lub niewyobrażalnym ${ }^{48}$. „Udaremnionym” doświadczeniem (a failed experience), używając sformułowania van Alphena, które „wyklucza możliwość dobrowolnie kontrolowanej pamięci wydarzenia"49. Czy istnieją w związku z tym jakieś granice reprezentacji Zagłady? Van Alphen uważa, że reprezentacja może wyrazić nawet ekstremalne doświadczenia:

[...] doświadczenie nie jest tak bezpośrednie i niezapośredniczone, jak się zwykle uważa, lecz jest fundamentalnie dyskursywne. [...] Formy doświadczenia nie zależą tylko od wydarzenia czy historii, która jest doświadczana, ale także od dyskursu, w którym to wydarzenie jest wyrażone/pomyślane/określone ${ }^{50}$.

Oczywiste wydaje się mówienie raczej o reprezentacji doświadczenia Zagłady w Ocalałym... niż o reprezentacji Zagłady jako takiej. Dla Narratora, jako świadka

45 R. Nycz, Poetyka doświadczenia..., dz. cyt., s. 142.

46 P. Ricœur, Pamięć, historia, zapomnienie, tłum. J. Margański, Kraków 2012, s. 24.

47 E. van Alphen, Symptoms of Discursivity: Experience, Memory, and Trauma, [w:] Acts of Memory. Cultural Recall in the Present, eds. M. Bal, J. V. Crewe, L. Spitzer, Hanover-London 1999, s. 27.

48 Por. A. L. Wlodarski, Musical Witness..., s. 18.

49 A. L. Wlodarski, Musical Witness..., s. 37.

${ }^{50}$ E. van Alphen, Symptoms of Discursivity..., dz. cyt., s. 24. 
i Ocalałego, powracające motywy muzyczne oraz „mimetyczny dialog pomiędzy wydarzeniami tekstowymi i muzycznymi” ${ }^{51}$ oznaczają ponowne przeżycie przeszłości. Jednak w introdukcji, w której Narrator nie wszedł jeszcze w swoją rolę świadka, są one muzycznie immanentne. Introdukcja ukazuje wszystkie motywy muzyczne, w tym również instrumentalną antycypację modlitwy Shema Yisroel, co daje wrażenie wysłuchania całej historii w przyspieszeniu (przypomina się tutaj odwrotny efekt - slow motion w Erwartung op. 17). Elementy onomatopeiczne stają się dźwiękami przetworzonymi przez umysł i pamięć Narratora, jako że nie pamięta on wszystkiego („I cannot remember ev'rything”) ${ }^{52}$. Posługując się terminologią Charlesa S. Peirce’a, dla postaci Narratora mają one wartość indeksalną, natomiast muzycznie - wartość ikoniczno-symboliczną. Jego doświadczenie jest doświadczeniem „udaremnionym”. Berel Lang zauważa, że „z definicji musi istnieć różnica między reprezentacją a jej przedmiotem niereprezentowanym, gdzie ta pierwsza dodaje własną wersję do reprezentowanego «oryginału»" ${ }^{33}$.

\section{„I cannot remember ev'rything”: rola pamięci}

W omawianym utworze pamięć zyskuje szczególny status, nie tylko w tekście, ale i w warstwie muzycznej. W swoich pismach Schönberg wielokrotnie kładł nacisk na rolę, jaką odgrywa ona w zrozumieniu i przyswajalności każdego dzieła muzycznego ${ }^{54}$. Zarówno zasady formy muzycznej, jak i techniki wariacyjnych powtórzeń służą uzyskaniu koherencji i zrozumiałości, które są według kompozytora najważniejszymi właściwościami dzieła z punktu widzenia odbiorcy. Powtórzenia, tekst $\mathrm{w}$ dużych formach atonalnych, seria w dodekafonii, decyzja o użyciu dysonansów i konsonansów - to wszystko jest podyktowane troską o zrozumiałość dzieła muzycznego. Schönberg pisał, nawiązując do Henri Bergsona: „Rozumienie opiera się na pamiętaniu. Pamiętanie opiera się na zdolności do zatrzymania wrażenia i jego świadomego przywołania, dobrowolnie lub niedobrowolnie"s5. Stąd już całkiem blisko do Husserlowskiego ujęcia teraźniejszości jako dynamicznego kompleksu aktów zbudowanych z praimpresji, retencji i protencji ${ }^{56}$. Zagadnieniem idącym $\mathrm{w}$ parze $\mathrm{z}$ omawianymi kwestiami jest koncepcja powtórzenia,

51 A. L. Wlodarski, Musical Witness..., s. 17.

52 „Nie mogę sobie wszystkiego przypomnieć".

53 A. Richardson, The Ethical Limitations of Holocaust Literary Representation, „eSharp”, issue 5, http://www.gla.ac.uk/media/media_41171_en.pdf (20.11.2015).

54 Por. A. L. Wlodarski, An Idea..., s. 590.

55 A. Schoenberg, The Musical Idea and the Logic, Technique, and Art of Its Presentation, Bloomington 2006, s. 110.

${ }_{56}$ Por. P. Borowiec, Czas polityczny po rewolucji 89. Czas w polskim dyskursie politycznym po 1989 roku, Kraków 2013, s. 66; zob. także: R. Ingarden, Utwór muzyczny i sprawa jego 
której zrozumienie ma ogromne znaczenie dla interpretacji twórczości zarówno teoretycznej, jak i muzycznej Schönberga. Bowiem „powtórzenie jest strukturalną zasadą koherencji”" ${ }^{27}$ i pełni funkcję czynnika jednoczącego w rozbudowanych formach muzycznych, zapewniając relacje pomiędzy sekcjami, a motyw manifestuje się tylko dzięki niemu. Według kompozytora nie wynaleziono dotąd innego fundamentalnego sposobu nadawania kształtu muzyce ${ }^{58}$. Pierwszym warunkiem zrozumienia jest pamięć, natomiast warunkiem wstępnym pamięci - rozpoznanie. Jeżeli figurze muzycznej brakuje charakteru lub jest zbyt skomplikowana, nie można jej ani zapamiętać, ani rozpoznać, a co za tym idzie, zrozumieć wszystkiego, co następuje ${ }^{59}$. Keith Salley podkreśla wpływ myśli Bergsona w odniesieniu zarówno do Schönbergowskiej techniki rozwijających się wariacji, jak i do roli pamięci w percepcji utworu muzycznego ${ }^{60}$. Dla Bergsona, który rozdziela doświadczenie przestrzenne od czasowego, przestrzeń jest „homogenicznym medium”, w którym obiekty mają granice i istnieją mierzalne odległości między nimi. Czas za to jest całkowicie subiektywny (wewnętrzny). Czyste trwanie nie jest przestrzenne, odnosi się ono do pamięci. Ta różnica pomiędzy chronometrycznym i psychologicznym doświadczeniem czasu została również podjęta przez Edmunda Husserla i Martina Heideggera ${ }^{61}$. Grupa motywów dźwiękowo-rytmicznych w Ocalałym $z$ Warszawy jest tak doskonale rozpoznawalna właśnie ze względu na zastosowanie przez kompozytora wyżej wspomnianych technik: ażurowej faktury sprzyjającej zrozumiałości, krótkiego czasu trwania utworu, mającego wpływ na koherencję oraz częstego powtarzania motywów, dzięki czemu zostają one rozpoznane i zatrzymane w pamięci. Motywy wykazują ponadto cechy charakterystyczne dla pamięci posttraumatycznej, w której wydarzenia powiązane z silnymi emocjami stają się dominujące i jednocześnie statyczne w swojej powtarzalności (fanfara trąbki), natomiast inne zacierają się w pamięci Narratora. Mając na uwadze znaczenie, jakie Schönberg przypisywał technice rozwijających się wariacji, można zauważyć silną opozycję elementu statycznego i dynamicznego w utworze. Narracja za sprawą motywów niepoddawanych wariacyjnym przekształceniom pozostaje statyczna (jako wspomnienie przeszłości). Zastosowanie powtarzających

tożsamości, [w:] Studia z estetyki, t. 2, Warszawa 1966, s. 280-283; tenże, O poznawaniu dzieła literackiego, [w:] Studia z estetyki, t. 1, Warszawa 1966 (zagadnienie „żywej pamięci”).

57 A. Schoenberg, Coherence, Counterpoint, Instrumentation, Instruction in Form, Lincoln 1994, s. 37.

58 A. Schoenberg, For a Treatise on Composition, [w:] Style and Idea, Berkeley-Los Angeles 1984, s. 265.

59 Por. A. Schoenberg, For a Treatise..., dz. cyt., s. 103.

${ }^{6}$ Por. K. Salley, On Duration and Developing Variation: The Intersecting Ideologies of Henri Bergson and Arnold Schoenberg, „Music Theory Online” 21 (2015) nr 4 (strony nienumerowane), http://www.mtosmt.org/issues/mto.15.21.4/mto.15.21.4.salley.html (15.12.2015).

${ }^{61}$ Por. K. Salley, On Duration..., dz. cyt., s. 3. 
się brzmień, instrumentacji, artykulacji, ostinata prowadzi do pewnej przewidywalności przebiegu muzycznego. Właściwie całe opowiadanie Ocalałego rozwija się muzycznie pomiędzy dwoma sferami: motywiczną - niezmienną, i rytmiczną, wprowadzającą wariantowość i ruch. Statyczny charakter przebiegu ulega zdynamizowaniu wraz z pojawieniem się modlitwy Shema Yisroel - seria ulega wtedy pełnemu rozwinięciu, a motywika i instrumentacja wyzwalają się spod tyranii repetycji. Głównym powodem jest zmiana czasu narracji z przeszłego na przeżywany tu i teraz, nieograniczony pamięcią.

\section{Mysterium iniquitatis}

Jak podkreśla Agamben: „powołaniem ocalałego jest pamiętanie, ocalały nie może nie pamiętać”62. Primo Levi przyznaje: „Wspomnienia o mojej niewoli są o wiele żywsze i bardziej szczegółowe niźli jakiekolwiek inne wspomnienia o tym, co wydarzyło się wcześniej i później”"63. Spostrzeżenie to dobrze oddaje specyfikę tekstu utworu Schönberga. Zapamiętane momenty kluczowe stanowią rodzaj kompasu w zdeformowanej czasoprzestrzeni. Pamięć Narratora nawiguje pomiędzy konkretnymi zdarzeniami, pozostałe sytuacje są niewyraźne i zamazane. Ernst van Alphen uważa, że taki sposób doświadczania Zagłady jest typowy dla pewnej kategorii ocalałych; badacz wskazuje na „brak fabuły lub ramy narracyjnej, dzięki której wydarzenia mogą być zrelacjonowane jako sensowna całość" ${ }^{4}$. Poczucie bezładu zostaje w ten sposób jeszcze bardziej podkreślone, na zasadzie kontrastu, przez pojawienie się jednoczącej modlitwy. Wedle słów Jana Pawła II zawartych w Przemówieniu wygłoszonym w Rzymie w 1994 roku modlitwa, która jako „podstawowy akt człowieka wierzącego jest wspólnym doświadczeniem wszystkich religii” oraz „aktem nadziei”, wyraża także „ogromną duchową moc, zwłaszcza kiedy towarzyszy jej poświęcenie i cierpienie”65. Symboliczna wartość modlitwy w zakończeniu utworu nabiera w tym świetle zupełnie nowego wymiaru. Podążając za myślą Giorgia Agambena, w „odartych z człowieczeństwa” warunkach obozu prawdopodobieństwo zaistnienia sceny takiej modlitwy było bliskie zeru. Jednak istnieją świadkowie, którzy przywołują scenę odmawiania przez więźniów modlitwy Shema Yisroel tuż przed wejściem do ciężarówek służących jako mobilne komory gazowe ${ }^{66}$. Posługując się terminologią Mieczysława Tomaszewskiego,

62 G. Agamben, Co zostaje z Auschwitz, dz. cyt., s. 25.

${ }_{63}$ P. Levi, Se questo è un uomo, dz. cyt., s. 225.

${ }^{64}$ E. van Alphen, Symptoms of Discursivity..., dz. cyt., s. 29.

65 Jan Paweł II, Przemówienie, Rzym 1994, [w:] M. Bunson, Siła wiary i umystu. Jan Paweł II, tłum. A. Gomola, Rebis, Poznań 2011, s. 126.

${ }^{66}$ Por. M. Strasser, „A Survivor from Warsaw”..., dz. cyt., s. 59, przyp. 19. 
możemy uznać modlitwę w Ocalałym $z$ Warszawy za rodzaj ex-tasis - „moment oderwania się od rzeczywistości realnej [...] i przeniesienia w nowy wymiar" ${ }^{\prime 67}$, "moment wyzwolenia się z aktualnego «tu i teraz», z historii i z miejsca na ziemi [...]"68. Wspólna modlitwa w Ocalałym... jest również mimo postawy poszukującej kompozytora wyrazem uznania wagi jedności w wierze i ma, jako taka, ważkie znaczenie symboliczne - „utracone wyznanie wiary” rozbrzmiewa nagle, zaświadczając nie tylko o tożsamości więźniów, ale także stanowiąc istotne przesłanie. Jest rodzajem „Zwycięstwa duchowego" ${ }^{69}$, któremu Jan Paweł II poświęca ważkie słowa: „Odnosili je ludzie różnych wyznań, różnych ideologii, zapewne nie tylko wierzący"70. Poprzez modlitwę Shema Yisroel Schönberg przywraca nie tylko godność ofiarom, przywraca im przede wszystkim człowieczeństwo. Jak pisze Jan Paweł II: „W obliczu zagłady i śmierci, w obliczu przemocy i okrucieństwa, nie mamy żadnej innej ucieczki poza Bogiem, do którego kierujemy nasze słowa i serca"71.

\section{Etyczne granice reprezentacji}

$\mathrm{W}$ ostatnich dekadach nastąpiła reinterpretacja kategorii reprezentacji jako „przesłania” lub uobecniania (niezakładającego odrębnego statusu ontologicznego ${ }^{72}$, która nie wydaje się właściwa dla analizy i interpretacji dzieł wcześniejszych. Co więcej, element dystansu pociąga za sobą problem wymiaru etycznego reprezentacji (możliwa versus niemożliwa, zakazana), na który zwracali szczególną uwagę m.in. Theodor W. Adorno, Jean-Luc Nancy czy Berel Lang, zwłaszcza w kontekście Zagłady. Granice reprezentacji mogą być ustanowione świadomie lub nieświadomie przez kompozytora, należą one również w związku z tym do samej istoty reprezentacji. Mogą być też wyznaczane przez różnorodne uwarunkowania: technikę kompozytorską, element zrozumiałości dzieła, dosłowność reprezentacji, postawę estetyczną i etyczną twórcy.

Reprezentacja w muzyce absolutnej mylona jest często, według Rogera Scrutona, z ekspresją, czyli obecnością przedmiotu bez jego opisu. Zdecydowane rozdzielenie kategorii reprezentacji i ekspresji przez Scrutona skutkuje jednak postawieniem pod znakiem zapytania istnienia problematyki ekspresji w utworach

${ }_{67}$ M. Tomaszewski, Muzyka w dialogu ze słowem, dz. cyt., s. 152.

${ }_{68}$ M. Tomaszewski, Muzyka w dialogu ze słowem, dz. cyt., s. 153.

${ }^{69}$ Jan Paweł II, Homilia w czasie mszy św. odprawionej na terenie byłego obozu koncentracyjnego, dz. cyt.

${ }^{70}$ Jan Paweł II, Homilia w czasie mszy św. odprawionej na terenie byłego obozu koncentracyjnego, dz. cyt.

${ }^{71}$ Jan Paweł II, Przemówienie, Rzym 1993, [w:] Siła wiary i umysłu, dz. cyt., s. 115.

72 Por. M. P. Markowski, Pragnienie obecności. Filozofie reprezentacji od Platona do Kartezjusza, Gdańsk 1999. 
z tekstem literackim i dziełach programowych. O granicach postawy etycznej Theodor W. Adorno pisał w następujący sposób:

Tak zwane artystyczne przedstawienie nagiego fizycznego bólu tych, którzy byli bici kolbami karabinów, zawiera, jakkolwiek zawoalowaną, możliwość czerpania z niego przyjemności. Moralność, która zabrania sztuce o tym zapomnieć, na sekundę osuwa się w otchłań swojego przeciwieństwa ${ }^{73}$.

Zarówno Adorno, jak i Lang zauważają, że „reprezentacja lub ukazanie w formie narratywnej doświadczenia Holocaustu z konieczności implikuje możliwość alternatywnej reprezentacji lub kontrnarracji”74. Anna Richardson uważa, że w świetle zaprzeczania Holocaustu taka reprezentacja jest nie tylko moralnie dozwolona, ale i konieczna ${ }^{75}$. Lydia Goehr wręcz postuluje przejście od reprezentacji do ekspresji w przypadku utworów nawiązujących do ekstremalnych doświadczeń ludzkich ${ }^{76}$.

Co różni autentycznego świadka Zagłady od kompozytora dającego świadectwo lub będącego po prostu „muzycznym świadkiem drugiego stopnia?”77. Według Agambena mamy tu do czynienia z dwoma wymiarami doświadczenia - jako dawania świadectwa i jako przeżycia (przetrwania) ${ }^{78}$. Filozof twierdzi, że przetrwanie czasami uzależnione było od determinacji, aby dać świadectwo. Pisze on również, iż „to, czemu niepodobna dać świadectwa, nosi jednak imię - w obozowym żargonie zwie się der Muselmann, muzułmanem"79.

Muzułman jest nie tylko i nie tyle granicą między życiem a śmiercią, wyznacza raczej próg między człowiekiem a istotą nieludzką. [...] Istnieje zatem punkt, w którym człowiek, choć zachowuje jeszcze pozór bycia człowiekiem, przestaje nim być ${ }^{80}$.

73 T. W. Adorno, Commitment, [w:] M. Rothberg, Traumatic Realism. The Demands of Holocaust Representation, Minneapolis 2000, s. 41.

74 A. Richardson, The Ethical Limitations of Holocaust..., dz. cyt., s. 5.

75 Por. A. Richardson, The Ethical Limitations of Holocaust..., dz. cyt., s. 5.

76 Por. L. Goehr, Elective Affinities. Musical Essays on the History of Aesthetic Theory, New York 2008, s. 201.

77 A. L. Wlodarski, Musical Witness..., s. 11.

78 Por. G. Agamben, Co zostaje z Auschwitz, dz. cyt., s. 135.

79 G. Agamben, Co zostaje z Auschwitz, dz. cyt., s. 41.

${ }^{80}$ G. Agamben, Co zostaje z Auschwitz, dz. cyt., s. 55. 
Jak zauważył George Steiner: „wiemy, że człowiek może czytać wieczorem Goethego lub Rilkego, grać Bacha i Schuberta, a rano iść do swojej codziennej pracy w Auschwitz" ${ }^{81}$. Agamben pisze, że:

Auschwitz oznacza kres i upadek wszelkiej postaci etyki godności i stosowania się do normy. Nagie życie, do którego sprowadzona została istota ludzka, niczego nie wymaga, ani do niczego się nie dostosowuje. Samo jest jedyną normą, jest całkowicie immanentne $e^{82}$.

Nawet cierpienie nie ma już głębi, gdyż nie istnieje dla niego odpowiedni kontekst czy przestrzeń. Wydaje się, że Agambenowskie rozumienie pojęcia homo sacer, człowieka świętego i przeklętego jednocześnie, może mieć odległe korzenie w filozofii Fryderyka Nietzschego:

Nagimi widziałem kiedyś obu, największego i najmniejszego człowieka, nazbyt podobni do siebie obaj - nazbyt ludzki nawet ten największy! Nazbyt mały ten największy - to był mój przesyt człowiekiem! I wieczny powrót tego najmniejszego! - to był mój przesyt wszelkim istnieniem $!^{83}$.

W Ocalałym $z$ Warszawy różnica między świadkiem a muzułmanem ujawnia się w kilku momentach. To dlatego modlitwa na końcu utworu ma tak ważkie znaczenie symboliczne - „utracone wyznanie wiary” nagle rozbrzmiewa i nie tylko zaświadcza o tożsamości więźniów, ale także stanowi przesłanie od wszystkich ocalałych: pamiętamy, kim byliście. Muzyka „kulminująca” i „zamykająca” łączą się tu w jedno ${ }^{84}$. Nacisk położony przez kompozytora na fakt, że przywoływany proces dehumanizacji w obozach odnosi się nie tyle do ich więźniów, ile do katów, ma ogromne znaczenie. Schönberg użycza głosu tym wszystkim, którzy nie mogą już ani przemawiać, ani śpiewać. W tym sensie w Ocalałym... pojawia się, tak rzadko obecny w muzyce XX wieku, wymiar katarktyczny (opisywany przez Mieczysława Tomaszewskiego), jako niezaprzeczalna wartość artystyczna i etyczna.

${ }^{81}$ L. Polony, Muzyka jako gra bycia. Wokót refleksji George’a Steinera o muzyce, „Estetyka i Krytyka" (2010) nr 2(19), s. 118.

${ }_{82}$ G. Agamben, Co zostaje z Auschwitz, dz. cyt., s. 69.

${ }_{83}$ F. Nietzsche, To rzekł Zaratustra. Książka dla wszystkich i dla nikogo, tłum. S. Lisiecka, Z. Jaskuła, Warszawa 2005, s. 212-213, [cyt. za:] G. Deleuze, Nietzsche, tłum. B. Banasiak, Łódź 2012, s. 136.

${ }^{84}$ Por. M. Tomaszewski, Muzyka w dialogu ze słowem, dz. cyt., s. 132. 


\section{Abstract}

\section{Holocaust in the thought of John Paul II and music of Arnold Schoenberg}

The purpose of this paper is to give a record of Arnold Schoenberg's engagement in the advocacy for human rights before and during the World War II, which reveals a special affinity with the thought of John Paul II. Further aim is to examine Schoenberg's dodecaphonic work A Survivor from Warsaw Op. 46 in terms of so called "secondary experience" of the Holocaust and as a tribute to the victims. The notion of experience will also serve as a methodological tool in this survey. It will help to reconstitute and differentiate the process of representing and expressing the experience of the Holocaust in music, specifically in music of Arnold Schoenberg. A Survivor from Warsaw Op. 46 for Narrator, men's chorus and orchestra came into existence two years after the World War II was finished. Schoenberg wrote the text himself including at the end of the piece a Jewish prayer Shema Yisroel. Apart from the textual and musical problematics, the work raises questions about aesthetical and ethical limits of representation of the Holocaust experience in music. 